\title{
The Sheriff and the Justices of William Rufus and Henry I.
}

A JTHORITIES on English constitutional history clearly recognize that the early itinerant justices were fiscal as well as judicial officials, although the usual approach to their activities has been from the judicial side. A strong reason for the use of the eyre is explained by an examination of methods in royal finance. ${ }^{1}$ The frequent and regular employment of the justice upon local mission is associated with the collection of revenues at large from judicial and other sources necessarily variable in amount and not included in the fixed ferm paid by the sheriff of the shire.

It is easy to slight the part which the justices played in the dispatch of non-judicial business. The Assize of Northampton ${ }^{2}$ in the time of Henry II provides that they are to receive oaths of fealty to the king, direct the render of homage and fealty to him, and see that certain castles are levelled to the ground. The Assize of $\mathrm{Arms}^{3}$ shows how in the same reign they employed knights and freemen to assess upon oath the value of chattels in each community in order to fix the military responsibility of its members; and they also forbade the export of timber and the purchase or sale of ships to be taken from the kingdom. The Pipe Rolls of the reign furnish abundant evidence that they levied tallages and directed the sheriff in the performance of various administrative duties. ${ }^{4}$ The heads of the pleas of the crown in the reign of Richard $I^{5}$ present a large and familiar range of duties laid upon them, most of which had to do with the king's financial rights rather than the administration of justice in any ordinary sense. The justices had not only come to control the sheriff in ways that are well understood. They had actually superseded him in the exercise of powers which he possessed in the early Norman period; for the Domesday sheriff, who was almost a viceroy, largely monopolized judicial, police, fiscal and administrative functions within his shire. Here, then, is a point of departure for tracing the rise of the justices.

I Stubbs inclined to the view (Benedictus II. p. viii) that it was at first a fiscal journey to assess tallages.

$2 \S \S 6.8$.

$3 \$ \$ 9,12$.

4 It is but rarely, however, that an itinerant justice is to be found in these records who devotes himself to exchequer business aloue.

5 See Adams and Stephens, Select Documents, no. 21. 
First of all, a comparison may be made between certain usages set forth in the Dialogus de Scaccario and those deducible from a document some forty-five years older, the Pipe Roll of Henry I. According to the Dialogus ${ }^{6}$ it is one of the difficult but important problems of the exchequer to determine whether the sheriffs who collect various kinds of accounts in different ways have acted as they should. The amount of ferm which they owe for their shires is of course known, and the amount of Danegeld can obviously be computed by the aid of records. But many debts due from individuals and communities must be acquitted according to the sheriff's statement unless some means of verification can be devised. Such accounts include murdra paid by hundreds, aids levied upon towns, and the income from the pleas of the crown. The check is provided by the rolls kept by the itmerant justices ${ }^{\tau}$ which enable the exchequer officials to make demand upon the sheriff ${ }^{8}$ for the exact amount of these several debts. The sheriff then a day or so in advance notifies those whose accounts he is settling at the exchequer, a procedure designed to assure publicity of accounts. ${ }^{9}$ The eyre and the roll of its proceedings make the king secure concerning essential portions of his income.

Did similar methods of accounting prevail in the year 1130 when the Pipe Roll of Henry I affords a glimpse of that king's fiscal system? The close correspondence in form between this record and the later Pipe Rolls is sufficient proof that the Dialogus is correct in representing the exchequer system of Henry II as a restoration ${ }^{10}$ of that of Henry I. Exchequer usage in 1130 repeats the main details already discovered in the Dialogus. The justices in Yorkshire, Walter Espec and Eustace fitz John, already authorized the sheriff to make certain expenditures in restoring the king's manors. ${ }^{11}$ The sheriff accounts for murdra and the aids of towns and counties, and the itinerant justices have visited many shires of the realm within the year. Nothing is said as to their keeping rolls, but officials who keep the pleas of the crown are mentioned more than once in this period. Over a decade earlier

'Oxford ed., I, iiii C.

T Ibid., II, i C.

8 Ibid., II, xii A.

9 III, iv E; p. 215.

10 Ibid., I viii G.

11 Pipe Roll 31 Henry I., p. 24. 
it was already a maxim of law that no man might dispute the recordatio of the king's court. ${ }^{12}$ In the Pipe Roll of 1130 specified sums due from placita and agreements before the justices are being demanded and paid at the exchequer. It has been doubted whether the sheriff as a rule collects these from individuals. ${ }^{13}$ But one Ulwinus de Bedewinda ${ }^{14}$ claims that he has turned over to the sheriff money that is due de placitis. Since the account stands in his name, not in the sheriff's, one may conclude again that usage is similar to that in the Dialogus and that the sheriff is the usual collector. But notwithstanding this fact, the evidence that the justices have reduced his independence in fiscal affairs is strong. Sir James Ramsey has shown ${ }^{15}$ that less than half of the revenue for this year was derived from the fixed sums which were included in the sheriff's farm.

The necessity of a counterfoil to the sheriff is especially clear because of the importance attached about 1130 to the revenues derived from pleas of the crown. It is well known that the justices were already making these a grievous means of extortion. ${ }^{16}$ Nor does anything novel appear in such organized exploitation. Ralph, the chancellor of Henry I, who died in 1123,17 and three of the best known justices of the king's curia, Ralph Basset, Hugh de Bochland and Geoffrey de Clinton, ${ }^{13}$ are among those accused of unjust oppression in a connotation which suggests judicial zeal in maintaining the king's material interest. A similar charge against two of the itinerant justices of 1130, Miles of Gloucester and Payn fitz John, ${ }^{18}$ is connected with the holding of pleas. It is significant that the author of the Leges Henrici by 1118 at the latest had made a careful study of the pleas not included in ferms ${ }^{20}$ the income from which went in toto to the king. This was a form of royal income readily capable of expansion. ${ }^{21}$ Bishop Herbert de Losinga, apparently in 1107, complained to Roger of Salisbury, the justiciar, that fifty pounds in pleas had been levied upon his lands

12 Leges Henrici, $31: 4$; $49: 4$.

13 Ramsay, Foundations of England, II, 328.

14 P. 20.

15 Foundations, II, 328.

16 Round, Geoffrey de Mandeville, 105.

17 Henry of Huntingdon, Rolls Series ed., 244.

18 Ordericus Vitalis, ed. Prevost, IV, 164-66.

18 Gesta Stephani, Rolls Series, 16.

$20 \S 10$ and passim.

21 The writer of the Gesta Stephani, Rolls Series ed., 17, complains that King Henry enmeshed the clergy placitis et legibus.. 
although his men had committeed no offense. ${ }^{22}$ The demand, significantly enough, was accompanied by one for military aid. In the earlier years of this reign as well as in the later years of William Rufus the Anglo-Saxon Chronicle frequently complains of high taxes which are sometimes laid for military purposes. These serve as a reminder that war revenues must be secure revenues, and that the reputation of the Norman sheriff could hardly offer much assurance in this regard. ${ }^{23}$ The systematic misuse of the judiciary for fiscal purposes certainly dates from the reign of William Rufus, this being a well-known device $^{24}$ of Ranulf Flambard. It is stated that the king made Ranulf exactor and placitator of the whole realm. The Charter of Liberties of Henry I indicates that chattels had been seized to satisfy these unjust claims, and that many of the debts which the new king pardoned at his accession had arisen through oppression of this kind.

How much earlier than 1130 the exchequer was able to make regular use of the itinerant justices in levying and collecting the king's revenue it is impossible to say. The Pipe Roll of that year mentions amounts due from placita held by Ralph Basset, a prominent justice probably deceased somewhat earlier. The special session over which he presided at Huncote in Leicestershire in $1124^{25}$ seems to be the earliest which is definitely recorded as transacting criminal business. There appears no good reason for holding that the frequent and systematic mission of judges from the king's curia was much older. It may be assumed that the justices who execute local commissions in the reign of William the Conqueror ${ }^{28}$ usually deal with but one cause. Known instances of more extended activity in this and the ensuing reign number but three. Despite the appointment in 1095 , and possibly again in 1096, of an itinerant commission ad investiganda regalia placita the justices from the curia as a rule can scarcely be disposing of fixed administrative routine. Indeed the Leges Henrici and the Leges Edwardi Confessoris clearly assume that the king's justice is a local resident ordinarily within reach when crimes are committed. ${ }^{27}$ It has been sug-

22 Goulburn and Symonds, Life of Herbert de Losinga, I, 229.

23 See English Historical Review, XXXIII, 170-73.

24 Florence of Worcester, Eng. Hist. Soc., II, 46.

25 Anglo-Saxon Chronicle.

28 Yale Law Journal, XXIII, 470-607.

27 Leges Henrici, $75: 6 \mathrm{a} ; 91 ; 92: 4 \mathrm{a}$. Leges Edw. Conf., 15; $20: 1 \mathrm{a} ; 20: 6$. 
gested, and the suggestion may be accepted with confidence, that the leges sometimes refer to the sheriff when they mention the justice. ${ }^{28}$

But it is certain that the local king's justice was not always the sheriff. Henry I in accord with usage employed by him also in Normandy ${ }^{29}$ actually gave appointment to special local justices. Besides the well-known iustitiarius of London and Middlesex, ${ }^{30}$ who belongs to the later years of the reign, there is mentioned a justicia of Cornwall and Devon. ${ }^{31}$ A writ form, newly modified in this reign, is addressed to justices as well as sheriffs in documents of the type heretofore directed to the county court. According to the account given in the Ramsey Chartulary ${ }^{32}$ the sheriff and the justice of the shire were associated as parties in a case against Abbot Aldwin involving possession of a certain great fish which the two officials wished to claim for the king. The Leges Henrici33 show that in the second decade of the reign either the justice or the sheriff might try offenders for theft, robbery, arson and other crimes. The fact agrees well with the accepted view that the local justices took over from the sheriff the pleas of the crown, ${ }^{34}$ ultimately to surrender them to the itinerant justices. That the local rather than the itinerant justice was acting in these matters seems to be shown by the general similarity of the office of the former to that of the coroner of a subsequent period, a similarity which was brought out by Professor Gross ${ }^{35}$ and which demands insistence. Thus, according to the Leges Edwardi Confessoris, ${ }^{36}$ the justicia regis had to do with the abjuration of the realm by criminals, and consequently performed a function of the thirteenth century coroner. Again, he had control ${ }^{37}$ over the bodies of persons who met death in an unknown manner. He also bore the judicial responsibility of the thirteenth century coroner. As to the capacity in which one Benjamin kept pleas of the crown in Norfolk in 1130

\footnotetext{
${ }^{28}$ Liebermann, Ueber die Leges Edwardi Confessoris, 73; Amer. Histor. Rev., VIII, 490.

29 Haskins, Norman Institutions, 100.

30 Round, Geoffrey de Mandeville, 110, 373.

31 Davis, Normans and Angevins, 523.

32 Rolls Series, I, 149.

33 66:9.

34 Round, Geoffrey de Mandeville, 373; Davis, Normans and Angevins, $138,523$. xvii.

${ }^{35}$ Pol. Sci. Quar., VII, 656-72; Sel. Coroners' Rolls, introd. pp. xv$3618: 2$.

${ }^{37}$ Leges Henrici, 92:12.
} 
there is difference of opinion. But the iustitiarius of London and Middlesex, mentioned above, had authority not only to do this but sole authority to try such pleas, thus excluding the sheriff from this function. The local justice, then, was apparently the precursor, just as at a later time the coroner was the helper, of the itinerant justice in safeguarding the king's fiscal interest. So far as record goes he was the royal agent who first permanently weakened the position of the powerful Norman shrievalty.

To attribute the existence of the local and the itinerant justice solely to fiscal motives would ignore other important factors in the case, such as the increase in the direct authority of the crown and the popularity which accrued to Norman rule through the maintenance of a firm peace; but the financial aspect of the problem was of major consequence. Attention may be called to another consideration which points to this conclusion. Evidence presented by Mr. H. W. C. Davis makes it probable that the local justice originated before the reign of Henry $I$. One particular form of diplomatic evidence upon which Mr. Davis appears to rely to prove this, ${ }^{38}$ and which might tend to show that the office dates from the Conqueror's reign, is inconclusive. ${ }^{30}$ Yet justices not clearly "justiciars of England"40 are mentioned by title in writs of William Rufus ${ }^{41}$ and a justice of this king locally tries a case ${ }^{42}$ of a kind which probably does not require the presence of a special curial representative. Ralph Passelewe, known as justitiarius of Norfolk in the reign of Henry I, seems to have held this position before Augnst, 1100. Mr. Davis finds that a certain cause tried during Ralph's justiciarship may date as early as 1091 , though not later than $1102 ; 43$ it may be added that in the reign of William Rufus he is found holding a Norfolk plea ${ }^{44}$ which involved a five pound forisfactura, presumably a crown plea which the king had granted away. The present writer has elsewhere ${ }^{45}$ made use of a passage which to him seems to point to the existence of this office in

38 Davis, Regesta, introd. pp. xxx-xxxi.

39 Ibid., I., no. 59.

40 Ibid., no. 424.

41 Ibid., nos. 366, 389, 448.

42 Davis, Normans and Angevins, 520; Monasticon, I., 143.

43 Normans and Angevins, 523; Ramsey Cart., I Rolls Series ed., 149.

44 Ramsey Chronicle, 211; Davis, Regesta, nos. 373, 448.

45 English Histor. Rev. XXXIII, 159. 
the reign of Rufus. An Abingdon chronicler ${ }^{48}$ in writing of this reign describes Hugh de Bochland as both sheriff of Berkshire and justiciar of public suminonses (compellationes) appointed by the king. The latter portion of the title hardly refers to Hugh's work at the king's curia, and the designation contrasts strongly with that of "justice in the whole realm of England," which Ralph Basset bears in the same work. ${ }^{47}$ On the other hand, Hugh's two offices seem to be on much the same level, and the appointment of this official associate of Flambard to the office of local justice is to be expected quite as much as his occupancy of the shrievalty of his county. A beginning of the segregation of the two offices would be easiest in this sort of case. The most probable interpretation of the passage is that this has taken place. On a priori grounds the use of the local justice fits into the fiscal scheme of Flambard just as the itinerant justice belongs to the exchequer system of 1130. The main fiscal idea perpetuated in the eyre is to be traced back to the earlier period, and in the light of recent research ${ }^{48}$ an improvement of curial methods of accounting in the reign of William Rufus is far from improbable. It is at least a highly interesting coincidence that this early use of the local justice associates itself with the ininistry of a man, reputed the great extortioner of his age, who drove his gemots over all England.

W. A. Morris.

Berkeley, California.

16 Chron. Monast. Abingdon, Rolls Ser., II, 43.

37 II, 170.

38 Eng. Histor. Rev. XXXII, 101-06. 